\title{
Respons Viabilitas Benih Kopi Arabica (Coffea arabica) terhadap Pelumuran Jamur Trichoderma viride di Pre-nursery
}

\section{(Viability Response of Arabica Coffee [Coffea arabica] Seed to Trichoderma viride Excision in Pre-nursery)}

\author{
Emi Sopiana ${ }^{1)}$, M. Tahir ${ }^{2 *}$, Albertus Sudirman ${ }^{2)}$ \\ 1) Program Studi Produksi dan Manajemen Industri Perkebunan Politeknik Negeri Lampung dan \\ 2) Jurusan Budidaya Tanaman Perkebunan Politeknik Negeri Lampung, Jl. Soekarno-Hatta No. 10 \\ Rajabasa, Bandar Lampung, 35144, Telp.: (0721) 703995, Fax.: (0721) 787309 \\ E-mail: tahir@polinela.ac.id
}

\begin{abstract}
Indonesia is the fourth largest coffee producing country in the world after Brazil, Vietnam, and Colombia. This study aims to obtain an optimal rate of Trichoderma viride on coffee seed viability, to obtain the highest growth of Arabica coffee clones, and to obtain interaction between rate of Trichoderma viride and Arabica coffee clones on viability of coffee seeds. The research was conducted in Nursery Farm, State Polytechnic of Lampung from October to December 2016. This research use factorial randomized block design (RBD). The first factor was the Arabica coffee clone i.e. Sigarar Utang clone and S 795 clone. The second factor was the rate of Trichoderma viride fungi culture i.e. $O_{0}$ (without Trichoderma viride fungi culture), $\mathrm{O}_{1}$ (100 $\mathrm{g}$ Trichoderma viride fungi culture), $\mathrm{O}_{2}$ (200 $\mathrm{g}$ of Trichoderma viride fungi culture), $\mathrm{O}_{3}$ (300 $\mathrm{g}$ of Trichoderma viride fungi culture). The variables observed included seed growth rate, germination rate, cotyledon rupture rate, hypocotyl height, hypocotyl diameter, normal sprouts, leaf area, root dry weight, and leaf dry weight. If there is a significant difference in $\alpha 0,05$, then the test is continue with the least significance difference test (LSD). The best treatment of Trichoderma viride fungi rate was $200 \mathrm{~g}$ can increase seed growth rate for 12 days, germination rate 80,28\%, and hypocotyl height 7,15 cm. The highest treatment in the Sigarar Utang clone can increase the height of hypocotyl 7,15 cm and the leaf area $14.39 \mathrm{~cm}^{2}$.
\end{abstract}

Keywords: Arabica coffee seed, Trichoderma viride fungi culture, seed growth rate

DOI: http://dx.doi.org/10.25181/jaip.v6i1.656

Diterima: 3 Januari 2018 / Disetujui: 20 April 2018 / Diterbitkan: 19 Mei 2018

\section{PENDAHULUAN}

Kopi merupakan salah satu tanaman komoditas perkebunan yang berperan penting bagi perekonomian nasional, khususnya sumber pendapatan dan devisa negara. Indonesia tercatat sebagai produsen kopi terbesar keempat di dunia setelah Brazil, Vietnam, dan Kolombia (Baso \& Anindita, 2018). Pada tahun 2012/2013 terjadi peningkatan produksi kopi terbesar mencapai 9,19 juta ton, musim 2013/2014 terjadi penurunan produksi sebesar minus 1,8\% dari periode sebelumnya menjadi 9 juta ton (PKPLN, 2014). Rendahnya produktivitas kopi rakyat disebabkan oleh sebagian besar tanaman kopi sudah tua, berasal dari varietas lokal/asalan yang dikembangkan oleh masyarakat, sebagian besar jenis bibit berasal dari bahan tanaman biji sapuan (tanpa pemilihan 
biji) dengan tingkat produktivitas relatif rendah (Aklimawati et al., 2015). Untuk itu salah satu faktor penentu keberhasilan pengembangan kopi tersebut yaitu adanya dukungan ketersediaan bahan tanam unggul dan bermutu.

Dalam proses budidaya, tanaman kopi dapat diperbanyak dengan dua cara yaitu generatif dan vegetatif. Perbanyakan generatif dilakukan dengan menggunakan biji sedangkan cara vegetatif yang umum dilakukan, yaitu dengan menyambung (grafting). Cara generatif memang memakan waktu yang lebih lama dibandingkan dengan grafting. Lamanya waktu perkecambahan benih kopi yaitu sekitar 3 bulan. Menurut Rozen \& Sutoyo (2012), penyebab lamanya perkecambahan adalah karena benih mempunyai stuktur kulit biji yang keras, kulit benih yang keras dapat mengakibatkan terhambatnya proses imbibisi atau proses masuknya air kedalam benih, sehingga dapat menghambat pertumbuhan dan perkembangan embrio. Hal inilah yang menyebabkan benih tersebut tidak dapat berkecambah dalam waktu yang relatif singkat. Oleh sebab itu, diperlukan perlakuan khusus dalam meningkatkan perkecambahan semai kopi.Pelumuran jamur Trichoderma dapat diperoleh efisiensi waktu dalam pembibitan dan menghemat biaya pemeliharaan, serta tingkat homogenitas bibit yang diperoleh cukup tinggi. Selain itu, jamur Trichoderma mudah didapat, dengan harga yang relatif murah bahkan dapat diperbanyak sendiri dengan media yang sederhana. Jamur Trichoderma dapat bertahan selama 3 bulan jika diletakkan dalam lemari pendingin. Aplikasi jamur Trichoderma sangat tepat dilakukan pada tanah karena dapat meningkatkan pertumbuhan tanaman.

Perkembangan jamur Trichoderma pada tanah akan mampu mengurai bahan organik yang ada di dalam tanah. Jamur Trichoderma sp. berfungsi menguraikan sellulosa dengan memproduksi enzim (Pratama et al., 2015). Trichoderma sp., selain sebagai pengendali juga merupakan dekomposer (pengurai) yang mencakup spektrum luas, dapat dijumpai dari lapisan seresah (atas) sampai lapisan humus (bawah) (Richards, 1994). Beberapa penelitian menunjukkan bahwa mikrob berperan atas perubahan kimiawi yang terjadi di dalam tanah. Peranan mikrob dalam beberapa siklus unsur hara yang penting, seperti siklus karbon, nitrogen, dan sulfur. Penelitian yang telah dilakukan oleh Rozen \& Sutoyo (2012) menunjukkan bahwa jamur Trichoderma dapat memecah dormansi benih Aren (Arenga pinnata) dengan pelumuran kulit benih pada suspensi Trichoderma. Pada penelitian ini benih yang digunakan berukuran lebih kecil dibandingkan pada penelitian sebelumnya. Diharapkan keberhasilan pada benih yang berukuran kecil akan lebih baik dan membutuhkan waktu yang singkat. Hal ini merupakan salah satu inovasi yang praktis dan efisien untuk dilakukan.

\section{METODE PENELITIAN}

Penelitian dilaksanakan di kebun praktik pembibitan dan laboratorium Politeknik Negeri Lampung dalam bentuk percobaan, yang dimulai dari bulan Oktober 2016 sampai dengan 
Desember 2016. Alat yang digunakan dalam penelitian ini adalah beaker glass, cangkul, golok, meteran, bambu, sungkup plastik, penggaris, jangka sorong, oven, kertas HVS, alat tulis, dan alat hitung. Bahan-bahan yang digunakan dalam penelitian ini adalah benih Kopi Arabika berasal dari Pusat Penelitian Kopi dan Kakao Jember, biakan jamur Trichoderma viride, akuades (sebagai pengencer), media tanah yang diayak, dan pasir yang diayak. Rancangan yang dipergunakan dalam penelitian ini adalah Rancangan Acak Kelompok (RAK), terdiri atas 2 faktor perlakuan dan 3 ulangan. Faktor pertama adalah varietas/klon kopi Arabika terdiri atas dua taraf yaitu Sigarar Utang $\left(\mathrm{K}_{1}\right)$ dan S $795\left(\mathrm{~K}_{2}\right)$. Faktor kedua adalah dosis biakan jamur Trichoderma viride yang terdiri atas empat taraf yaitu tanpa biakan jamur Trichoderma viride $\left(\mathrm{O}_{0}\right), 100 \mathrm{~g}$ biakan jamur Trichoderma viride $\left(\mathrm{O}_{1}\right), 200 \mathrm{~g}$ biakan jamur Trichoderma viride $\left(\mathrm{O}_{2}\right), 300 \mathrm{~g}$ biakan jamur Trichoderma viride $\left(\mathrm{O}_{3}\right)$. Setiap satuan percobaan terdiri atas 30 benih.

Pengamatan yang dilakukan dalam penelitian ini adalah kecepatan tumbuh benih (hari), daya berkecambah, kecepatan kotiledon pecah, tinggi hypocotyl, diameter hypocotyl, kecambah normal, luas daun, serta berat kering akar dan daun. Data yang diperoleh diuji dengan sidik ragam. Pengujian dilanjutkan dengan Uji Beda Nyata Terkecil (BNT) pada taraf nyata 5\%.

\section{HASIL DAN PEMBAHASAN}

\section{Kecepatan Tumbuh Benih (hari)}

Hasil analisis varians terhadap kecepatan tumbuh benih menunjukkan bahwa terdapat perbedaan yang nyata pada perlakuan dosis biakan jamur Trichoderma, akan tetapi pada perlakuan varietas serta interaksi antara dosis biakan jamur dengan varietas tidak berpengaruh terhadap kecepatan tumbuh benih (Tabel 1).

Tabel 1. Respons dosis jamur Trichoderma viride terhadap kecepatan tumbuh (hari)

\begin{tabular}{lc}
\hline \multicolumn{1}{c}{ Perlakuan } & Rerata kecepatan tumbuh benih (hari) \\
\hline $\mathrm{O}_{0}=$ Tanpa jamur $T$. viride & $15,0^{\mathrm{d}}$ \\
$\mathrm{O}_{1}=$ dosis $100 \mathrm{~g}$ jamur $T$. viride & $13,3^{\mathrm{c}}$ \\
$\mathrm{O}_{2}=$ dosis $200 \mathrm{~g}$ jamur $T$. viride & $12,3^{\mathrm{a}}$ \\
$\mathrm{O}_{3}=$ dosis $300 \mathrm{~g}$ jamur $T$. viride & $12,7^{\mathrm{b}}$
\end{tabular}

Keterangan: Rerata pada kolom yang sama diikuti oleh huruf yang tidak sama menunjukkan beda nyata dengan uji BNT pada tingkat taraf 5\%

Berdasarkan Tabel 1, kecepatan tumbuh benih tanpa pelumuran jamur Trichoderma lebih lambat dibandingkan dengan pelumuran jamur Trichoderma. Pada pelumuran jamur Trichoderma dengan dosis $200 \mathrm{~g}$ ternyata memiliki waktu lebih cepat dibandingkan dengan dosis lainnya. Hasil ini diperkuat oleh laporan Asaduzzaman (2003) yang menyatakan bahwa aplikasi Trichoderma 
pada benih cabai dapat meningkatkan indeks vigor benih dan mempercepat perkecambahan benih. Menurut Nurahmi et al. (2012) dan Novariza et al. (2015), jamur Trichoderma berpotensi sebagai pemacu tumbuh atau stimulator pertumbuhan tanaman. Dari sifat tersebut, maka benih dapat tumbuh dengan cepat. Penelitian sebelumnya yang dilakukan oleh Chamzurni et al. (2011) tentang uji produksi indol-3-acetic acid (IAA) oleh jamur Trichoderma diketahui bahwa jamur Trichoderma memproduksi hormon IAA yang ada keterkaitannya dengan aspek pertumbuhan dan perkembangan tanaman, dari embrio sampai reproduksi tanaman. Pemberian hormon pada benih sangat penting dilakukan karena hormon merupakan peransang untuk mempercepat proses berlangsungnya benih dalam berkecambah. Secara visual dan morfologis biji yang berkecambah umumnya ditandai dengan keluarnya radikula yang menonjol dari biji.

\section{Daya Berkecambah (\%)}

Hasil analisis varians terhadap daya kecambah menunjukkan bahwa terdapat perbedaan yang nyata pada perlakuan dosis biakan jamur Trichoderma, akan tetapi pada perlakuan varietas serta interaksi antara dosis biakan jamur dengan varietas tidak berpengaruh terhadap daya berkecambah (Tabel 2).

Tabel 2. Respons dosis jamur Trichoderma viride terhadap daya berkecambah benih (\%)

\begin{tabular}{lc}
\hline \multicolumn{1}{c}{ Perlakuan } & Rerata daya kecambah (\%) \\
\hline $\mathrm{O}_{0}=$ Tanpa jamur $T$.viride & $76,39^{\mathrm{c}}$ \\
$\mathrm{O}_{1}=$ dosis $100 \mathrm{~g}$ jamur $T$. Viride & $77,78^{\mathrm{b}}$ \\
$\mathrm{O}_{2}=$ dosis $200 \mathrm{~g}$ jamur $T$. Viride & $80,28^{\mathrm{a}}$ \\
$\mathrm{O}_{3}=$ dosis $300 \mathrm{~g}$ jamur $T$. Viride & $76,11^{\mathrm{c}}$
\end{tabular}

Keterangan: Rerata pada kolom yang sama diikuti oleh huruf yang tidak sama menunjukkan beda nyata dengan uji BNT pada tingkat taraf 5\%

Tabel 2 menunjukkan bahwa nilai daya kecambah benih tertinggi terdapat pada pelumuran jamur Trichoderma viride dengan dosis 200 g yaitu sebesar 80,28\% dibandingkan dengan perlakuan lainnya. Nilai daya kecambah pada benih sebesar minimal $80 \%$ merupakan syarat umum untuk program perbenihan (Mulsanti et al., 2014). Nilai daya berkecambah yang diperoleh di dalam penelitian ini menandakan bahwa secara umum sudah sesuai target di dalam program perbenihan. Di dukung oleh penelitian Rozen \& Sutoyo (2012) menyatakan bahwa jamur Trichoderma dapat mematahkan benih aren dari 8 bulan menjadi 3 bulan, karena jamur Trichoderma merupakan jamur yang bersifat antagonis. Dari sifat antagonis tersebut jamur dapat merombak kulit benih, sehingga terjadinya perobekan pada kulit benih, maka proses imbibisi dapat berlangsung yang menyebabkan benih dapat berkecambah dengan cepat. Faktor lain karena di bantu oleh adanya hormon IAA yang terkandung pada jamur Trichoderma. Hormon IAA mampu 
mamatahkan dormansi biji dan akan merangsang proses perkecambahan biji, dari hormon inilah dapat digunakan sebagai pemacu benih untuk berkecambah.

\section{Kecepatan Kotiledon Pecah (hari)}

Hasil analisis varians terhadap kecepatan kotiledon pecah menunjukkan bahwa terdapat perbedaan yang nyata pada perlakuan dosis biakan jamur Trichoderma, akan tetapi pada perlakuan varietas serta interaksi antara dosis biakan jamur dengan varietas tidak berpengaruh terhadap kecepatan kotiledon pecah (Tabel 3).

Tabel 3. Respons dosis jamur Trichoderma viride terhadap kecepatan kotiledon pecah (hari)

\begin{tabular}{lc}
\hline \multicolumn{1}{c}{ Perlakuan } & Rerata kecepatan kotiledon pecah (hari) \\
\hline $\mathrm{O}_{0}=$ Tanpa jamur $T$. viride & $39,17^{\mathrm{d}}$ \\
$\mathrm{O}_{1}=$ dosis $100 \mathrm{~g}$ jamur $T$. viride & $35,00^{\mathrm{c}}$ \\
$\mathrm{O}_{2}=$ dosis $200 \mathrm{~g}$ jamur $T$. viride & $33,50^{\mathrm{b}}$ \\
$\mathrm{O}_{3}=$ dosis $300 \mathrm{~g}$ jamur $T$. viride & $32,67^{\mathrm{a}}$
\end{tabular}

Keterangan: Rerata pada kolom yang sama diikuti oleh huruf yang tidak sama menunjukkan beda nyata dengan uji BNT pada tingkat taraf 5\%

Berdasarkan Tabel 3, terlihat bahwa waktu yang dibutuhkan untuk kecepatan kotiledon pecah sekitar 32,67 hari. Dari semua perlakuan yang diberikan ternyata perlakuan pelumuran jamur Trichoderma viride dengan dosis $300 \mathrm{~g}$ memberikan waktu yang lebih cepat dibandingkan dengan tanpa pelumuran jamur Trichoderma yaitu 32,67 hari. Keberhasilan pada penelitian ini diduga karena besarnya dosis yang digunakan, sehingga banyaknya kandungan spora yang menyelimuti benih, dengan banyaknya spora, maka dapat memudahkan jamur tersebut dalam proses perobekan pada kotiledon, sehingga dapat menyebabkan membukanya kotiledon dengan cepat yang akan menjadi calon daun. Dengan terbukanya kotiledon menandakan bahwa benih tersebut sudah memasuki stadium kepelan.

\section{Tinggi Hypocotyl (cm)}

Hasil analisis varians terhadap tinggi hypocotyl menunjukkan bahwa terdapat perbedaan yang nyata pada perlakuan dosis biakan jamur Trichoderma dan perlakuan varietas, akan tetapi interaksi antara dosis biakan jamur dengan varietas tidak berpengaruh terhadap tinggi hypocotyl (Tabel 4). Tabel 4 menunjukkan bahwa varietas yang Sigarar Utang memberikan respons pertumbuhan tinggi hypocotyl lebih besar yaitu sebesar 7,39 cm dibandingkan dengan varietas $\mathrm{S} 795$ yaitu sebesar 6,49 $\mathrm{cm}$. Varietas Sigarar Utang memberikan hasil yang lebih baik kemungkinan karena diduga benih yang digunakan merupakan benih yang berukuran besar, sehingga mempengaruhi pertumbuhan tinggi hypocotyl. Benih yang berukuran besar lebih cenderung cepat berkecambah. Aulia et al. 
(2014) menyatakan bahwa laju pertumbuhan biji yang berukuran besar lebih cepat dibandingkan dengan biji yang berukuran kecil, dikarenakan pada biji berukuran besar terdapat cadangan makanan yang lebih banyak. Cadangan makanan pada benih berupa karbohidrat, lemak atau minyak dan protein.Cadangan makanan ini merupakan energi benih untuk berkecambah . Pertumbuhan benih terus berlangsung sampai pertumbuhan tinggi bibit, sehingga tinggi hypocotyl akanterus meningkat.

Tabel 4. Respons varietas terhadap tinggi hypocotyl $(\mathrm{cm})$

\begin{tabular}{lc}
\hline \multicolumn{1}{c}{ Perlakuan } & Rerata tinggi hypocotyl $(\mathrm{cm})$ \\
\hline $\mathrm{K}_{1}=$ varietas Sigarar Utang & $7,39^{\mathrm{a}}$ \\
$\mathrm{K}_{2}=$ varietas S 795 & $6,49^{\mathrm{b}}$
\end{tabular}

Keterangan: Rerata pada kolom yang sama diikuti oleh huruf yang tidak sama menunjukkan beda nyata dengan uji BNT pada tingkat taraf 5\%

Hasil analisis BNT pada tingkat signifikan 5\% terhadap tinggi hypocotyl ternyata menunjukkan bahwa dosis biakan jamur Trichoderma viride terbaik adalah dosis $200 \mathrm{~g}$ (Tabel 5). Tabel 5 menunjukkan bahwa dosis yang memberikan hasil terbaik terdapat pada pelumuran jamur Trichoderma viride dengan dosis $200 \mathrm{~g}$ dibandingkan dengan tanpa pelumuran jamur Trichoderma viride. Hal ini diduga karena jamur Trichoderma viride mengandung hormon IAA. Seperti yang dikemukakan oleh Hanafiah (2005) yang menyatakan bahwa pengaruh hormon IAA pada pertumbuhan tanaman adalah dalam peninggian batang, sehingga pertumbuhan tinggi hypocotyl meningkat dikarenakan adanya hormon IAA.

Tabel 5. Respons dosis jamur Trichoderma viride terhadap tinggi hypocotyl (cm)

\begin{tabular}{lc}
\hline \multicolumn{1}{c}{ Perlakuan } & Rerata tinggi hypocotyl $(\mathrm{cm})$ \\
\hline $\mathrm{O}_{0}=$ Tanpa jamur $T$. viride & $6,58^{\mathrm{c}}$ \\
$\mathrm{O}_{1}=$ dosis $100 \mathrm{~g}$ jamur $T$. viride & $6,99^{\mathrm{b}}$ \\
$\mathrm{O}_{2}=$ dosis $200 \mathrm{~g}$ jamur $T$. viride & $7,15^{\mathrm{a}}$ \\
$\mathrm{O}_{3}=$ dosis $300 \mathrm{~g}$ jamur $T$. viride & $7,04^{\mathrm{b}}$
\end{tabular}

Keterangan: Rerata pada kolom yang sama diikuti oleh huruf yang tidak sama menunjukkan beda nyata dengan uji BNT pada tingkat taraf $5 \%$

\section{Diameter Hypocotyl (mm)}

Hasil analisis varians menunjukkan bahwa perlakuan varietas dan dosis jamur Trichoderma viride tidak berpengaruh terhadap diameter hypocotyl serta tidak terdapat interaksi antara varietas dan dosis jamur Trichoderma viride. Hal ini diduga karena pertumbuhan diameter hypocotyl bergantung pada sistem perakaran. Menurut Pertiwi et al. (2016) menyatakan bahwa akar berfungsi 
sebagai jalan masuk unsur hara dalam tanah ke tanaman untuk pertumbuhan dan perkembangan tanaman. Apabila sistem perakaran terhambat, maka proses pembelahan dan pembesaran sel menjadi terhambat, sehingga tidak adanya peningkatan aktivitas kambium yang menyebabkan diameter hypocotyl tidak bertambah.

\section{Kecambah Normal (\%)}

Hasil analisis varians terhadap kecambah normal menunjukkan bahwa terdapat perbedaan yang nyata pada perlakuan dosis biakan jamur Trichoderma, akan tetapi pada perlakuan varietas serta interaksi antara dosis biakan jamur dengan varietas tidak berpengaruh terhadap kecambah normal (Tabel 6).

Tabel 6. Respons dosis jamur Trichoderma viride terhadap kecambah normal (\%)

\begin{tabular}{lc}
\hline \multicolumn{1}{c}{ Perlakuan } & Rerata kecambah normal (\%) \\
\hline $\mathrm{O}_{0}=$ Tanpa jamur $T$. viride & $73,33^{\mathrm{c}}$ \\
$\mathrm{O}_{1}=$ dosis $100 \mathrm{~g}$ jamur $T$. viride & $86,67^{\mathrm{b}}$ \\
$\mathrm{O}_{2}=$ dosis $200 \mathrm{~g}$ jamur $T$. viride & $75,00^{\mathrm{c}}$ \\
$\mathrm{O}_{3}=$ dosis $300 \mathrm{~g}$ jamur $T$. viride & $90,00^{\mathrm{a}}$
\end{tabular}

Keterangan: Rerata pada kolom yang sama diikuti oleh huruf yang tidak sama menunjukkan beda nyata dengan uji BNT pada tingkat taraf 5\%

Tabel 6 menunjukkan bahwa dosis jamur Trichoderma viride memberikan nilai kecambah normal yang tertinggi adalah terdapat pelumuran jamur Trichoderma viride dengan dosis $300 \mathrm{~g}$ yaitu sebesar 90\% dan nilai kecambah normal terendah adalah tanpa pelumuran jamur Trichoderma viride sebesar 73,33\%. Hal ini dapat terjadi karena sesuai dengan pemanfaatan jamur Trichoderma viride yang digunakan sebagai pengendalian hayati. Pemberian dosis jamur yang diberikan semakin tinggi, maka spora jamur yang menempel pada benih semakin banyak, sehingga benih terlindungi dari patogen atau mikroorganisme yang dapat merusak pertumbuhan pada benih. Pemakaian dosis yang tinggi tidak merusak sel-sel jaringan embrio melainkan benih dapat tumbuh dengan normal.

Hasil penelitian ini sejalan dengan hasil penelitian Saputri et al. (2015) yang menujukkan bahwa jamur Trichoderma yang diaplikasikan dengan benih menyebabkan daya infeksi dari patogen pada benih kedelai semakin kecil, sehingga tanaman masih dapat tumbuh dengan normal. Jika benih yang ditanam dalam keadaan tanpa adanya infeksi patogen, maka bibit yang dihasilkan dapat tumbuh dengan normal.

\section{Luas Daun $\left(\mathrm{cm}^{2}\right)$}

Hasil analisis varians terhadap luas daun menunjukkan bahwa terdapat perbedaan yang nyata pada perlakuan varietas, akan tetapi pada perlakuan dosis biakan jamur Trichoderma serta 
interaksi antara dosis biakan jamur dengan varietas tidak berpengaruh terhadap luas daun (Tabel 7). Berdasarkan Tabel 7, luas daun yang tertinggi terdapat pada varietas Sigarar Utang sebesar 14,39 $\mathrm{cm}^{2}$ sedangkan luas daun yang terendah terdapat pada varietas $\mathrm{S} 795$ sebesar $13,24 \mathrm{~cm}^{2}$. Hal ini diduga karena ketersediaan cahaya matahari yang cukup, sehingga mengakibatkan luas daun meningkat. Daun merupakan organ utama tempat berlangsungnya fotosintesis. Menurut Nugroho \& Yuliasmara (2012) menyatakan bahwa parameter luas daun digunakan untuk mengukur kandungan total klorofil, jadi semakin besar nilai luas daun yang didapat, maka kandungan klorofil semakin besar dikarenakan peningkatan penyerapan cahaya matahari.

Tabel 7. Respons varietas terhadap luas daun $\left(\mathrm{cm}^{2}\right)$

\begin{tabular}{lc}
\hline \multicolumn{1}{c}{ Perlakuan } & Rerata luas daun $\left(\mathrm{cm}^{2}\right)$ \\
\hline $\mathrm{K}_{1}=$ varietas Sigarar Utang & $14,39^{\mathrm{a}}$ \\
$\mathrm{K}_{2}=$ varietas S 795 & $13,24^{\mathrm{b}}$ \\
\hline
\end{tabular}

$\overline{\text { Keterangan: Rerata pada kolom yang sama diikuti oleh huruf yang tidak sama menunjukkan beda }}$ nyata dengan uji BNT pada tingkat taraf 5\%

\section{Berat Kering Akar dan Daun (g)}

Hasil analisis varians menunjukkan bahwa perlakuan varietas dan dosis jamur Trichoderma viride tidak berpengaruh terhadap berat kering akar dan daun, lalu tidak adanya interaksi antara varietas dengan dosis jamur Trichoderma viride. Hal ini diduga karena cadangan endosperm yang tersedia pada benih sedikit, sehingga benih tidak mendapatkan nutrisi dalam pembentukan organ daun maupun akar. Semakin bertambahnya umur bibit, maka kandungan endosperm semakin menurun karena kandungan endosperm telah terserap oleh benih yang akan tumbuh. Hal inilah diduga endosperm tidak lagi digunakan dalam pertumbuhan kecambah karena ketersediaan endosperm habis terpakai. Endosperm digunakan sebagai sumber nutrisi bagi embrio untuk bertumbuh dan berkembang yaitu untuk perkecambahan hingga terbentuk organ daun serta organ akar.

\section{KESIMPULAN DAN SARAN}

\section{Kesimpulan}

Dari hasil percobaan disimpulkan bahwa aplikasi pelumuran jamur Trichoderma viride terhadap benih dengan dosis $200 \mathrm{~g}$ untuk tiap 30 benih memberikan respons terbaik terhadap variabel kecepatan tumbuh benih, daya kecambah, kotiledon pecah, dan kecambah normal; sedangkan varietas yang memberikan respons lebih baik terhadap variabel tinggi hypocotyl dan luas daun yaitu Sigarar Utang. 


\section{Saran}

Penulis menyarankan agar dilakukan penelitian lanjutan tentang respons pertumbuhan vegetatif di pembibitan main-nursery untuk melihat respons jamur Trichoderma viride terhadap varietas kopi Arabika Sigarar Utang dan S 795.

\section{DAFTAR PUSTAKA}

Aklimawati, L., Sumarno, D., \& Mawardi, S. (2015). Effect of service quality on coffee based economic cluster development on farmers and other stakeholders satisfaction in Bondowoso District. Pelita Perkebunan, 31(1), 59-72.

Asaduzzaman, M., Alam, M. J., \& Islam, M. M. (2013). Effect of Trichoderma on seed germination and seedling parameters of chili. Journal of Science Foundation, 8(1-2), 141-150.

Aulia, R., Rosmayati, R., \& Bayu, E. S. (2014). Respon pertumbuhan dan produksi beberapa varietas kedelai hitam (Glycine max L.) berdasarkan ukuran biji. Agroekoteknologi, 2(4), 1324-1331.

Baso, R. L., \& Anindita, R. (2018). Analisis daya saing kopi Indonesia. Jurnal Ekonomi Pertanian dan Agribisnis, 2(1), 1-9.

Chamzurni, T., Sriwati, R., \& Rahel, R. (2011). Efektivitas dosis dan waktu aplikasi Trichoderma virens terhadap serangan Sclerotium rolfsii pada kedelai. Jurnal Floratek, 6(1), 62-73.

Hanafiah, K. A., Anas, I., Napoleon, A., \& Ghoffar, N. (2005). Biologi tanah: Ekologi dan Makrobiologi Tanah. Jakarta: Raja Grafindo Persada.

Mulsanti, I. W., Wahyuni, S., \& Sembiring, H. (2014). Hasil padi dari empat kelas benih yang berbeda. Jurnal Penelitian Pertanian Tanaman Pangan, 33(3).

Novariza, D. A., Lubis, L., Sitepu, S. F., \& Tistama, R. (2015). Exploration and characterization of microorganisms from rubber seed and the benefits for rubber plant growth (Hevea brasiliensis Muell. Arg.). Agroekoteknologi, 4(1), 1925-1936.

Nugroho, K. W., \& Yuliasmara, F. (2012). Penggunaan metode scanning untuk pengukuran luas daun kakao. Warta Pusat Penelitian Kopi dan Kakao Indonesia, 24(1), 5-8.

Nurahmi, E., Susanna, S., \& Sriwati, R. (2012). Pengaruh Trichoderma terhadap perkecambahan dan pertumbuhan bibit kakao, tomat, dan kedelai. Jurnal Floratek, 7(1), 57-65.

Pertiwi, N. M., Tahir, M., \& Same, M. (2016). Respons pertumbuhan benih kopi robusta terhadap waktu perendaman dan konsentrasi giberelin (GA3). Jurnal Agro Industri Perkebunan, 4(1), $1-11$.

PKPLN [Pusat Kebijakan Perdagangan Luar Negeri]. (2014). Analisis Komoditas Kopi dan Karet Indonesia: Evaluasi Kinerja Produksi, Ekspor dan Manfaat Keikutsertaan dalam Asosiasi Komoditas Internasional. Jakarta: Badan Pengkajian Dan Pengembangan Kebijakan Perdagangan Kementerian Perdagangan.

Pratama, R. E., Mardhiansyah, M., \& Oktorini, Y. (2015). Waktu potensial aplikasi mikoriza dan Trichoderma spp. untuk meningkatkan pertumbuhan semai Acacia mangium. Jurnal Online Mahasiswa (JOM) Bidang Pertanian, 2(1), 1-11. 
Richards, B. N. (1994). The Microbiology of Terrestrial Ecosystems. Singapura: Longman Singapura Publisher Ltd.

Rozen, N., \& Sutoyo, C. (2012). Pematahan dormansi benih aren (Arenga pinnata) dengan pelumuran kulit benih pada suspensi Trichoderma. Jurnal Jerami, 4(3), 162-168.

Saputri, E., Lisnawita, L., \& Pinem, M. I. (2015). Enkapsulasi beberapa jenis Trichoderma sp. pada benih kedelai untuk mengendalikan penyakit Sclerotium rolfsii Sacc. Agroekoteknologi, 3(3), 1123-1131. 